\title{
Characteristics of quinolone and beta-lactam antibiotic resistance in Salmonella isolated from raw meat in Ho Chi Minh City
}

\author{
Truong Huynh Anh $\mathrm{Vu}^{1,2^{*}}$, Nguyen Hoang Khue Tü, Chu Van Hai \\ Huynh Yen $\mathrm{Ha}^{1}$, Nguyen Anh Duc ${ }^{3}$ \\ ${ }^{1}$ Microbiology laboratory, Center of Analytical Services and Experimentation HCMC (CASE), \\ Ho Chi Minh City, Vietnam \\ ${ }^{2}$ Faculty of Biological Sciences, Nong Lam University, Ho Chi Minh City, Viet Nam \\ ${ }^{3}$ School of Biotechnology, HCMC International University, Vietnam National University of \\ Ho Chi Minh City, Vietnam
}

(Received: 02/04/2021; Accepted: 04/06/2021)

\section{Abstract}

In this study, a total of 380 raw meat samples (pork, beef, and chicken) were collected randomly from traditional markets in Ho Chi Minh City (Vietnam). Salmonella strains were isolated by cultivation methods according to ISO 6579-1:2017, and subsequently confirmed by PCR method (TCVN 8342:2010). These strains were used to test antibiotic susceptibility in six kinds of antibiotics belonging to two groups of quinolones (nalidixic, ciprofloxacin, and ofloxacin), and $\beta$-lactam antibiotics (ampicillin, amoxicillin, cephalexin) together with the detection of their resistant genotypes was estimated by Kirby-Bauer method and multiplex PCR. It was noted that the proportion of Salmonella spp. contaminated samples was $42.37 \%$ (161/380). Specifically, Salmonella spp. strains found in $50.00 \%(63 / 126), 49.62 \%(65 / 131)$, and $26.83 \%$ (33/123) of pork, chicken, and beef samples, respectively. It was noticed that all isolated strains were resistant to six types of antibiotics. The highest proportion was $22.98 \%$ for ampicillin (AM), followed by $10.56 \%$ for nalidixic acid (NA). The proportions of amoxicillin/ acid clavulanic (AMC), ceftazidime (CAZ), ciprofloxacin (CIP), and ofloxacin (OPX) resistant strains were remarkably low $(<10 \%)$. There were 37/161 (22.98\%) Salmonella strains carrying TEM genes and 5/161 (3.11\%) carrying CTX genes. On the other hand, there was no strain carrying SHV genes. Four quinolone-resistant genes including gyrA, gyrB involved in nalidixic acid resistance, and parC, parE involved in ofloxacin and ciprofloxacin resistance were detected in all Salmonella strains that also carried $\beta$-lactamase encoding genes. It is important to note that blaTEM-gyrA/B-parC/E genes were simultaneously found in all tested strains. While the proportion of strains containing blaCTX-gyrA/B-parC/E genes was $40.54 \%$, the proportion of strains carrying blaTEM/CTX-gyrA/B-parC/E genes was $5.41 \%$. The results revealed that raw meat might be contaminated with Salmonella spp. that are highly resistant to $\beta$-lactam antibiotics and quinolones. Henceforth, it is necessary to establish monitoring and surveillance programs on Salmonella spp. contamination and their antibiotic sensitivity in Vietnam to protect consumers' health. The study also provided direct evidence for Salmonella contamination and antibiotic resistance situation in Ho Chi Minh City.

Keywords: beta-lactam, quinolone, antibiotic susceptibility, antibiotic-resistant gene, raw meat, Salmonella. 


\section{INTRODUCTION}

The emergence of antibiotic resistance in bacteria raises global problems in public health [1-2]. Among them, the increase of Gram-negative bacteria resistance to antibiotics, especially $\beta$-lactam, and quinolone is tremendously remarkable. $\beta$-lactams and quinolones are antibiotics commonly utilized in human treatment [3]. Salmonella is resistant to $\beta$-lactam antibiotics due to their ability to produce $\beta$-lactamase that hydrolyzes $\beta$-lactam antibiotics. Over 340 genes involving $\beta$-lactamase have been found and classified into blaTEM, blaOXA, blaPER, blaPSE, blaSHV, blaCTX-M, and blaCMY. However, these genes are distributed in bacteria differently. Salmonella that resists tetracycline was investigated due to among of these genes [4].

Quinolones are used in treating multi-drug resistance Salmonella infection in humans and veterinary because of their broad-spectrum effect. In the case of Salmonella species that originated from foodstuffs, quinolone resistance is mostly mentioned in the list of WHO's important antibiotics in medical published in 2017 [3]. The mechanism of action of quinolone is the inhibition of topoisomerase II, DNA gyrase, and topoisomerase IV, which are involved in bacterial DNA synthesis, transcription, and cell division, respectively. Quinolone resistance in Salmonella is categorized into two mechanisms: (1) mutation of gyrA and gyrB encoding DNA gyrase, and parC encoding topoisomerase IV, and (2) increase in the action of Acr ABTolC efflux pumps. Quinolone resistance is usually acquired by the combination of multiple mutations rather than a single mutation [5]. However, in Gram-negative bacteria, quinolones impact DNA gyrase, then topoisomerase IV, inhibiting transcription of bacteria [6]. Plasmids carrying $q n r$ genes have been found to mediate quinolone resistance. These genes encode pentapeptide-repeat proteins that block the action of ciprofloxacin on bacterial DNA gyrase and topoisomerase IV [7]. In Salmonella, quinolone/fluoroquinolone resistance most commonly occurs due to mutations in the genes encoding DNA gyrase and topoisomerase IV. Uncontrolled use of the antibiotic could impose selective pressure on the organism which may lead to the emergence of resistant strains [8].

As mentioned above, this study aimed to evaluate the contamination level of Salmonella belonging to group of quinolone and $\beta$-lactam antibiotic resistance characteristics strains isolated from raw meat collected from traditional markets in Ho Chi Minh City (Vietnam). The results would contribute knowledge on antibiotic resistance status in Salmonella spp. isolated from foods in Vietnam.

\section{MATERIALS AND METHODS}

\subsection{Strains}

Salmonella isolates were recovered from raw meat samples from traditional markets in Ho Chi Minh City.

\subsection{Methods}

\subsubsection{Calculation of sample size}

The sample size of the study was determined by applying the formula presented below:

$$
n=\frac{z^{2}(p \cdot q)}{e^{2}}
$$


Note:

$-z$ is the distribution value corresponding to a $95 \%$ confidence level, then $\mathrm{z}$-score is 1.96 ;

- $p$ is the estimated percentage of the food that did not meet the microbiological criteria of a previous study, $p=0.4$ (with the rate of food that did not meet the microbiological criteria was $43.75 \%)$;

- $e$ : expected accuracy level is 0.05 [9].

The sample size required for the study must be equal to or greater than 376 samples.

\subsubsection{Sample collection and preservation}

A total of 380 raw meat samples (pork: 126, beef: 123, chicken: 131) were collected from traditional markets in some districts of Ho Chi Minh City from 8 am to 9 am for 12 months (09/2019 - 09/2020). A portion of 150 - 1,500 g of each sample was collected for the study [10]. The samples were transported to the laboratory as soon as possible for immediate analysis. It should not take longer than 12 hours.

\subsubsection{Salmonella spp. isolation}

Salmonella spp. isolation was based on ISO 6579-1:2017 [11]. The enrichment of samples was done by incubating the mixture of $25 \mathrm{~g}$ samples with $225 \mathrm{~mL}$ Buffer Peptone Water-BPW (Merck/1.07228) at $37^{\circ} \mathrm{C}$ in $18 \pm 2$ hours. Then, bacteria were isolated by using Selective media. Bacteria were cultivated to enrich in Rappaport Vassiliadis medium with soya-RV (Merck/1.07700) at $41.5^{\circ} \mathrm{C}$ in $24 \pm 3$ hours and Kauffmann tetrathionate novobiocin-MKTTn (Merck $/ 1.05878)$ at $37^{\circ} \mathrm{C}$ in $24 \pm 3$ hours. The pure bacteria were spread on Xylose Lysine Deoxycholate (XLD) agar (Merck/1.05287), and Mannitol Lysine Crystal Violet Brilliant Green agar-MLCB (Oxoid/CM0783). And then, it was incubated at $37^{\circ} \mathrm{C}$ for $24 \pm 3$ hours.

\subsubsection{DNA analysis}

An incubated loop was used to pick up colonies on Nutrient Agar plate (Merck/1.05450), and transferred into an Eppendorf tube containing 1-mL distilled water. DNA isolation was performed by using AccuRive pDNA Prep Kit (KT Biotech).

\subsubsection{Salmonella spp. confirmation by PCR}

The suspected colonies of Salmonella spp. were confirmed by PCR using invA primers (Table 1) [14].

PCR ingredients were prepared according to TCVN 8342:2020 [14], thermal cycler on Mastercycler (Eppendorf): $95^{\circ} \mathrm{C} / 5$ minutes $\left(1\right.$ cycle); $95^{\circ} \mathrm{C} / 60$ seconds; $54^{\circ} \mathrm{C} / 45$ seconds and $72^{\circ} \mathrm{C} / 60$ seconds ( 35 cycles); $72^{\circ} \mathrm{C} / 10$ minutes ( 1 cycle). 
Table 1. Primer sequences used for PCR

\begin{tabular}{|c|c|c|c|c|}
\hline Target & Primer & Sequence 5'-3' & Size $(b p)$ & Reference \\
\hline \multirow{2}{*}{$\operatorname{Inv} A$} & $\operatorname{Inv} \mathrm{A} 1$ & TTGTTACGGCTATTTTGACCA & \multirow{2}{*}{520} & \multirow{2}{*}[14]{} \\
\hline & $\operatorname{Inv} \mathrm{A} 2$ & CTGACTGCTACCTTGGCTGATG & & \\
\hline \multirow{6}{*}{ Beta-lactam } & \multirow{2}{*}{ blaTEM } & GGTCGCCGCATACACTATTCTC & \multirow{2}{*}{372} & \multirow{6}{*}[15]{} \\
\hline & & TTTATCCGCCTCCATCCAGTC & & \\
\hline & \multirow{2}{*}{ blaSHV } & CCAGCAGGATCTGGTGGACTAC & \multirow{2}{*}{231} & \\
\hline & & CCGGGAAGCGCCTCAT & & \\
\hline & \multirow{2}{*}{ blaCTX } & CCCATGGTTAAAAAACACTGC & \multirow{2}{*}{950} & \\
\hline & & CAGCGCTTTTGCCGTCTAAG & & \\
\hline \multirow{8}{*}{ Quinolone } & \multirow{2}{*}{ gyrA } & CGTTGGTGACGTAATCGGTA & \multirow{2}{*}{251} & \multirow{8}{*}[16]{} \\
\hline & & CCGTACCGTCATAGTTATCC & & \\
\hline & \multirow{2}{*}{ gyrB } & GCGCTGTCCGAACTGTACCT & \multirow{2}{*}{181} & \\
\hline & & TGATCAGCGTCGCCACTTCC & & \\
\hline & \multirow{2}{*}{ parC } & CTATGCGATGTCAGAGCTGG & \multirow{2}{*}{270} & \\
\hline & & TAACAGCAGCTCGGCGTATT & & \\
\hline & \multirow{2}{*}{ parE } & TCTCTTCCGATGAAGTGCTG & \multirow{2}{*}{240} & \\
\hline & & ATACGGTATAGCGGCGGTAG & & \\
\hline
\end{tabular}

\subsubsection{Evaluation of antibiotics susceptibility of Salmonella strains}

Salmonella isolates were tested for susceptibility to six antibiotics belonging to the $\beta$-lactam group and quinolones. Inhibition zones were recorded and evaluated according to the guidance of CLSI 2018 (M100-S28) [12].

The antibiotics used in this study were selected according to national action plan of Ministry of Agriculture and Rural Development (Vietnam) [13]. Sterile $6 \mathrm{~mm}$-diameter disks (Oxoid/England) were immersed in antibiotic solutions with certain concentrations such as ampicillin (AM, $10 \mu \mathrm{g} / \mathrm{mL}$ ), amoxicillin/acid clavulanic (AMC, $30 \mu \mathrm{g} / \mathrm{mL}$ ), ceftazidime (CAZ, $30 \mu \mathrm{g} / \mathrm{mL}$ ), ciprofloxacin (CIP, $5 \mu \mathrm{g} / \mathrm{mL}$ ), ofloxacin (OFX, $5 \mu \mathrm{g} / \mathrm{mL}$ ), and nalidixic acid (NA, 30 $\mu \mathrm{g} / \mathrm{mL})$.

\subsubsection{Detection of resistant genes in Salmonella strains by multiplex PCR}

The primers for blaTEM, blaSHV, and blaCTX genes, gyrA, gyrB genes together with parC, parE genes involving in $\beta$-lactam antibiotics, nalidixic, ciprofloxacin and ofloxacin resistance, respectively were shown in Table 1.

Multiplex PCR ingredients included AmpliTaq Gold 2 UI; $0.2 \mathrm{mM}$ dNTP; $1.5 \mathrm{mM} \mathrm{MgCl}$; $1 \mathrm{X}$ buffer; $0.5 \mu \mathrm{L}$ each primer $(0.625 \mu \mathrm{M}) ; 5 \mu \mathrm{L}$ DNA template and de-ion water up to $25 \mu \mathrm{L}$. Thermal cycle on Mastercycler (Eppendorf):

For blaTEM, blaSHV, and blaCTX genes, the PCR program was set up at $95^{\circ} \mathrm{C} / 2$ minutes, $95^{\circ} \mathrm{C} / 30$ seconds, 25 cycles $\left(60^{\circ} \mathrm{C} / 90\right.$ seconds and $72^{\circ} \mathrm{C} / 90$ seconds), and $68^{\circ} \mathrm{C} / 10$ minutes. 
For detection of quinolones resistant genes, the PCR condition was performed at $95^{\circ} \mathrm{C} / 10$ minutes, 32 cycles $\left(95^{\circ} \mathrm{C} / 1\right.$ minute, $52^{\circ} \mathrm{C} / 01$ minute, $72^{\circ} \mathrm{C} / 30$ seconds $)$, and $72^{\circ} \mathrm{C} / 10$ minutes.

\subsubsection{Gel electrophoresis}

PCR products were run on gel agarose $1.5 \%$ containing $1 \mu \mathrm{g} / \mathrm{mL}$ ethidium bromide in TBE. The duration was 35 - 40 minutes in $100 \mathrm{~V}$ and $100 \mathrm{~mA}$. Then, the gel was visualized by UV in Ingenius capture machine.

\section{RESULTS AND DISCUSSION}

\subsection{Prevalence of Salmonella isolates in raw meat}

Analysis methods were based on the previous studies [11, 14] for detection of Salmonella spp. in raw meat samples taken from markets. Results were illustrated in Table 2.

Table 2. The percentage of Salmonella spp. detection in raw meat samples

\begin{tabular}{cccccc}
\hline & & \multicolumn{2}{c}{ Positive } & \multicolumn{2}{c}{ Negative } \\
\cline { 3 - 6 } Samples & No. & $n$ & Percentage (\%) & $n$ & Percentage (\%) \\
\cline { 3 - 6 } Pork & 126 & 63 & 50.00 & 63 & 50.00 \\
\hline Beef & 123 & 33 & 26.83 & 90 & 73.17 \\
\hline Chicken & 131 & 65 & 49.62 & 66 & 50.38 \\
\hline Total & $\mathbf{3 8 0}$ & $\mathbf{1 6 1}$ & $\mathbf{4 2 . 3 7}$ & $\mathbf{2 1 9}$ & $\mathbf{5 7 . 6 3}$ \\
\hline
\end{tabular}

The results revealed that among 380 collected samples, there were 161 samples infected by Salmonella spp., accounting for $42.37 \%$ (161/380). Pork and chicken detected the approximate proportions at $50.00 \%(63 / 126)$ and $49.62 \%(65 / 131)$. The lowest proportion of contamination occurred in beef samples with the rate of $26.83 \%(33 / 123)$.

There were several differences in the comparison of this study and others. According to the proportion of multiple - microbial contamination in raw meat from markets in Ha Noi city, Do Ngoc Thuy and co-authors [17] have stated that Salmonella spp. occurrence was in chicken (47.1\%), pork (27.3\%), and beef (19\%). In Ho Chi Minh city, this surveillance was revealed a higher number, compared to the survey of Le Van Du, and co-authors [9] which was reported that the proportion of Salmonella spp. detected in pork and chicken samples were $43.75 \%$, and $37.24 \%$, respectively. The research of authors from Pasteur Institute in Ho Chi Minh city (eventually collected 1,150 raw samples including pork, chicken, and beef from markets in the city) showed that the proportion of raw meat contaminated by Salmonella spp. was 32.26\% [18].

\subsection{Antibiotics susceptibility of Salmonella spp. strains}

Salmonella spp. showed resistance to all six kinds of antibiotics in the study (Table 3). The proportion of AM resistant strains was ranked the highest (22.98\%), while the AMC resistant strains were the lowest $(1.86 \%)$. The proportions of resistance to the other antibiotics were 
10.56\% (NA), 4.97\% (CIP), 3.73\% (OFX), and 3.11\% (CAZ). Regarding the isolated origins, the proportion of Salmonella strains isolated from chicken, which resisted to each antibiotic, represented a higher number than others. Meanwhile, all Salmonella spp. strains isolated from beef were sensitive to AMC, and CAZ. In terms of AM, chicken-isolated Salmonella spp. strains had a higher portion (29.23\%), compared to $22.22 \%$ for pork, and $12.12 \%$ for beef. Beef-isolated Salmonella spp. strains showed the lowest resistance among other samples.

Table 3. Antibiotics susceptibility of Salmonella spp.

\begin{tabular}{|c|c|c|c|c|c|c|c|c|}
\hline \multirow{2}{*}{ Antibiotics } & \multicolumn{2}{|c|}{ Pork $(n=63)$} & \multicolumn{2}{|c|}{ Beef $(n=33)$} & \multicolumn{2}{|c|}{ Chicken $(n=65)$} & \multicolumn{2}{|c|}{ Total $(n=161)$} \\
\hline & $\begin{array}{c}\text { Resistant } \\
\text { strains }\end{array}$ & $\%$ & $\begin{array}{c}\text { Resistant } \\
\text { strains }\end{array}$ & $\%$ & $\begin{array}{c}\text { Resistant } \\
\text { strains }\end{array}$ & $\%$ & $\begin{array}{c}\text { Resistant } \\
\text { strains }\end{array}$ & $\%$ \\
\hline$A M C$ & 02 & 3.17 & 00 & 00 & 01 & 1.54 & 03 & 1.86 \\
\hline$A M$ & 14 & 22.22 & 04 & 12.12 & 19 & 29.23 & 37 & 22.98 \\
\hline$C A Z$ & 02 & 3.17 & 00 & 00 & 03 & 4.62 & 05 & 3.11 \\
\hline$N A$ & 05 & 7.94 & 01 & 3.03 & 11 & 16.92 & 17 & 10.56 \\
\hline$C I P$ & 04 & 6.35 & 01 & 3.03 & 03 & 4.62 & 08 & 4.97 \\
\hline OFX & 02 & 3.17 & 01 & 3.03 & 03 & 4.62 & 06 & 3.73 \\
\hline
\end{tabular}

Abbreviation: Amoxicillin/Clavunic acid (AMC), Ampicillin (AMP), Ceftazidime (CAZ), Nalidixic acid (NA), Ciprofloxacin (CIP), Ofloxacin (OFX)

The sensitivity of $\beta$-lactams, and quinolones antibiotics in this study represented significant differences compared to the results of Thai and co-authors (2012), recorded on 189 Salmonella strains isolated from pork and poultry in Northern provinces. This article indicated that there were $39.8 \%$, and $27.8 \%$ of Salmonella stains resisted to AMP, and NA, respectively [19]. In the provinces in central Vietnam, Tran Thi Thuy Nga, and co-authors [20] revealed that the percentage of antibiotic resistant Salmonella spp. strains isolated from raw meats in these provinces were 41.6\% (AM), 15.0\% (NA), and 2.7\% (CIP). In Ho Chi Minh city, Le Van Du, and co-authors [9] examined 39 Salmonella spp. strains isolated from chicken and pork that had the percentage of resistance corresponding to AM (76.92\%), and CIP (23.08\%), respectively.

The antibiotic resistant Salmonella strains detected in foodstuff are able to transmit to humans through unsafety food chains. Especially, it will be problematic for treating the strains that resist broad-spectrum quinolones, and cephalosporin antibiotics because these drugs are usually recommended for monitoring and curing infection by Salmonella in human bodies [21].

\subsection{Characteristics of genes encoding ESBL in Salmonella spp. strains}

Extended-spectrum $\beta$-lactamases (ESBLs) were a rapidly evolving group of $\beta$-lactamases which shared the ability to hydrolyze third-generation cephalosporins and aztreonam yet were inhibited by clavulanic acid. Typically, they derive from genes for TEM-1, TEM-2, or SHV-1 by mutations that alter the amino acid configuration around the active site of these $\beta$-lactamases. This extended the spectrum of $\beta$-lactam antibiotics susceptible to hydrolysis by these enzymes. 
The results in Table 4 and Figure 1 showed that 37/161 (22.98\%) Salmonella strains containing TEM genes encoding ESBL and 5/161 (3.11\%) containing CTX genes. There was no case recorded for SHV genes. This study resembled the results of Tran Thi Thuy Nga and co-authors [20]. TEM genes were detected in Salmonella strains isolated from beef were higher than that in pork and chicken with 10/33 (30.30\%), 15/63 (23.81\%), and 12/65 (18.46\%), respectively. Besides, CTX genes detected in Salmonella strains originated from the chicken was $3 / 65$ (4.62\%), followed by $1 / 33$ (3.03\%) for beef, and 1/63 (1.59\%) for pork.

Table 4. Distribution of genes encoding ESBL in Salmonella spp. strains

Genes encoding ESBL, $n(\%)$

\begin{tabular}{cccc}
\hline & blaTEM, $\boldsymbol{n}(\%)$ & blaCTX, $\boldsymbol{n}(\%)$ & blaSHV, $\boldsymbol{n}(\%)$ \\
\hline Pork $(\boldsymbol{n}=\mathbf{6 3})$ & $15(23.81)$ & $01(1.59)$ & $0(0)$ \\
\hline Chicken $(\boldsymbol{n}=\mathbf{6 5})$ & $12(18.46)$ & $03(4.62)$ & $0(0)$ \\
\hline Beef $(\boldsymbol{n}=33)$ & $10(30.30)$ & $01(3.03)$ & $0(0)$ \\
\hline Total $(\mathrm{n}=\mathbf{1 6 1})$ & $\mathbf{3 7 ( 2 2 . 9 8 )}$ & $\mathbf{0 5}(\mathbf{3 . 1 1})$ & $\mathbf{0}(\mathbf{0})$ \\
\hline
\end{tabular}

Comparing to CAZ resistance presented in Table 3, 5/5 strains (100\%) contained $\beta$-lactamase encoded blaCTX genes. CAZ is an antibiotic involve in $3^{\text {rd }}$ generation cephalosporin family that is hydrolyzed by $\beta$-lactamases.

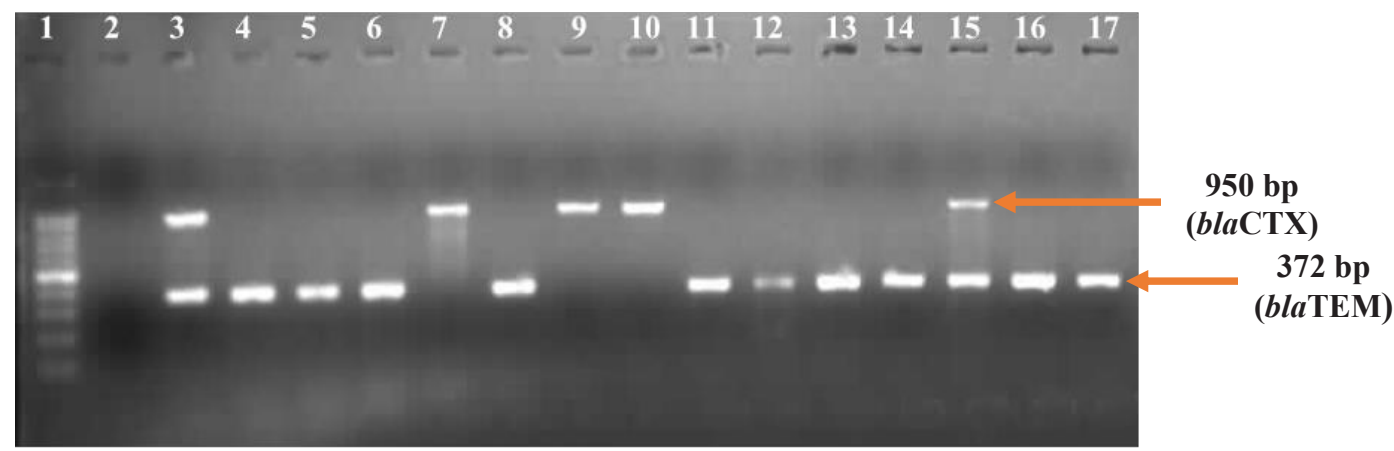

Figure 1. Electrophoretogram of PCR products of genes encoding ESBL in Salmonella spp. strains (1: Lane M: 100 bp DNA Marker, 2: Negative control, 3: Positive control, 4-17:

Salmonella spp. carrying the blaTEM and blaCTX genes)

\subsection{Detection of genes responsible for the resistance of quinolones in Salmonella spp. producing ESBL}

There were detected genes involving nalidixic acid resistance including gyrA, gyr B, ofloxacin, and ciprofloxacin resistance including parC, parE. Data in Table 5 showed that all 37 Salmonella spp. strains contained quinolone resistant genes, corresponding to $100 \%$. The strains were genes of blaTEM-gyrA/B-parC/E occupied the higher rate of detection in comparison with blaCTX-gyrA/B-parC/E and blaTEM/CTX-gyrA/B-parC/E, corresponding to 100\%, 40,54\%, and $5,41 \%$, respectively. 
Regarding the origins, chicken-originated Salmonella strains had a higher rate of ESBL gene detection than that from pork. Especially, two strains contained both genes encoding $\beta$-lactamase (blaTEM/CTX), and genes encoding quinolones resistance (gyrA/B; parC/E) corresponding to $16.67 \%$ (2/12) (Table 5, and Figure 2).

Table 5. The proportion of quinolones-resistant Salmonella spp. producing ESBL

\begin{tabular}{ccccc}
\hline & $\begin{array}{c}\text { Pork } \\
(\boldsymbol{n}=\mathbf{1 5})\end{array}$ & $\begin{array}{c}\text { Chicken } \\
(\boldsymbol{n}=\mathbf{1 2})\end{array}$ & $\begin{array}{c}\text { Beef } \\
(\boldsymbol{n}=\mathbf{1 0})\end{array}$ & $\begin{array}{c}\text { Total } \\
(\boldsymbol{n}=37)\end{array}$ \\
\cline { 2 - 5 } & $\boldsymbol{n}(\boldsymbol{\%})$ & $\boldsymbol{n}(\%)$ & $\boldsymbol{n}(\%)$ & $\boldsymbol{n}(\%)$ \\
\hline pyrA/B & $15(100.00)$ & $12(100.00)$ & $10(100.00)$ & $37(100.00)$ \\
\hline blaTEM-gyrA/B-parC/E & $15(100.00)$ & $12(100.00)$ & $10(100.00)$ & $37(100.00)$ \\
\hline blaCTX-gyrA/B-parC/E & $01(6.67)$ & $03(25.00)$ & $01(10.00)$ & $15(40.54)$ \\
\hline blaTEM/CTX-gyrA/B-parC/E & $0(00)$ & $02(16.67)$ & $0(00)$ & $02(5.41)$ \\
\hline
\end{tabular}

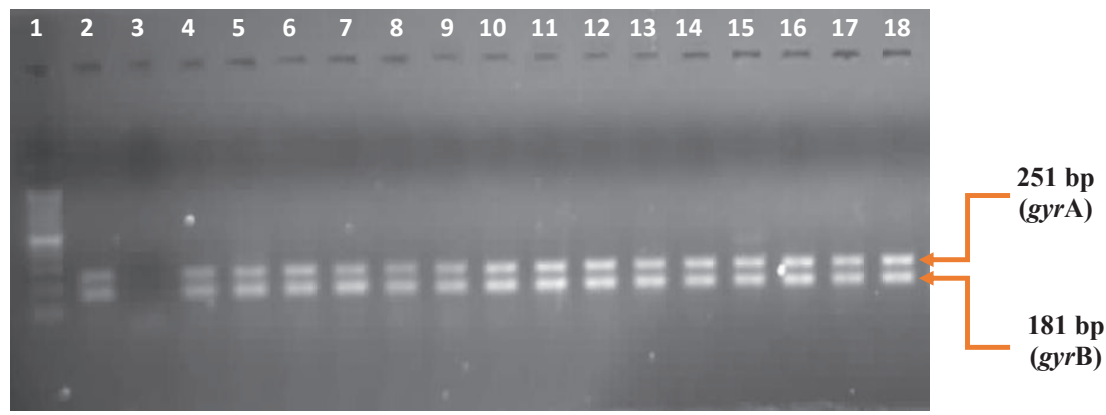

Figure 2. Electrophoretogram of PCR products of genes gyrA and gyrB in Salmonella spp. strains (1: Lane M: 100 bp DNA Marker, 2: Positive control, 3: Negative control, 4-18:

Salmonella spp. carrying the gyr $A$ and gyrB genes)

\section{CONCLUSION}

The percentage of Salmonella spp. detected in raw meats was $42.37 \%$. Pork and chicken samples were contaminated by Salmonella 50.00\% (63/126) and 49.62\% (65/131), while beef samples showed a $26.83 \%(33 / 123)$ contaminated rate. The isolated Salmonella strains resisted to all the tested antibiotics. Among them, the portion of AM was ranked in the highest rate (22.98\%), and that of AMC was $1.86 \%$ which was the smallest. The proportions of the remaining antibiotics were $10.56 \%$ (NA), 4.97\% (CIP), 3.73\% (OFX), and 3.11\% (CAZ). It was noticed that there were $37 / 161(22.98 \%)$, and 5/161 (3.11\%) Salmonella strains containing gene encoding ESBL involving TEM and CTX resistance, respectively. All ESBL producing Salmonella strains contained four genes involving quinolone resistance including gyrA, gyrB for nalidixic acid resistance; parC, parE for ofloxacin, and ciprofloxacin resistance. The strains including simultaneously genes blaTEM-gyrA/B-parC/E demonstrated the higher rate of detection in comparison with blaCTX-gyrA/B-parC/E, and blaTEM/CTX-gyrA/B-parC/E corresponding to $100 \%, 40.54 \%$, and $5.41 \%$, respectively. The study showed that Salmonella resisted $\beta$-lactam 
antibiotics, and quinolones, although they were isolated from retail meat from traditional markets in Ho Chi Minh City after antibiotic susceptibility testing and resistant genes. The results of this study provided direct evidence about foodborne Salmonella contamination and transmission of multi-drug resistant strains in Ho Chi Minh City (Vietnam).

\section{ACKNOWLEDGEMENT}

This study was supported financially by scientific and technological tasks contract No. 70/2019/HD-QPTKHCN.

\section{REFERENCES}

[1]. E. J. Klemm, V. K. Wong, G. Dougan, "Emergence of dominant multidrug-resistant bacterial clades: Lessons from history and whole-genome sequencing," Proceedings of the National Academy of Sciences, vol. 115, no. 51, pp. 12872-12877, 2018.

[2]. L. Maka, M. Popowska, "Antimicrobial resistance of Salmonella spp. isolated from food," Roczniki Państwowego Zakładu Higieny, vol. 67, no. 4, pp. 343-358, 2016.

[3]. WHO CIA list, "Critically important antimicrobials for human medicine", World Health Organization, 2017.

[4]. O. A. Mascaretti, Bacteria versus antibacterial agents. mBio, 2003.

[5]. M. G. Abatcha, Z. Zakaria, D. G. Kaur, K. L. Thong, "Review Article: Atrends of Salmonella and antibiotic resistance," Advanced Sciences and Technologies, vol 17, pp. 9-21, 2014.

[6]. V. V. Moudgal, G. W. Kaatz, "Fluoroquinolone resistance in bacteria," Antimicrobial Drug Resistance. pp. 195-205, 2009.

[7]. L. Martínez-Martínez, A. Pascual, G. A. Jacoby, "Quinolone resistance from a transferable plasmid," Lancet, vol. 351, no. 9105, pp. 797-799, 1998.

[8]. M. Gopal, S. Elumalai, S. Arumugam, V. Durairajpandian, M. A. Kannan, E. Selvam, S. Seetharaman, "GyrA ser83 and ParC trp106 mutations in Salmonella enterica serovar typhi isolated from typhoid fever patients in tertiary care hospital," Journal of Clinical and Diagnostic Research, vol. 10, no. 7, pp. 14-18, 2016.

[9]. L. V. Du, H. T. K. Hoa, "Current situation of lean substance and anti-biotic residues, and Salmonella contamination in pork and chicken in Ho Chi Minh city," Journal of Science and Engineering in Agriculture and Forestry, vol. 5, pp. 46-55, 2017.

[10]. Circular No. 14/2011/TT-BYT, "General instruction of food sampling for inspection, food quality, food safety control," Ministry of Health, 2011.

[11]. ISO 6579-1:2017, Microbiology of the food chain - Horizontal method for the detection, enumeration and serotyping of Salmonella - Part 1: Detection of Salmonella spp.

[12]. CLSI, Performance Standards for Antimicrobial Susceptibility Testing. 28th ed. CLSI supplement M100. Wayne, PA: Clinical and Laboratory Standards Institute.

[13]. Decision No. 2625/QD-BNN-TY, Nation Action Plan on anti-biotic use management and prevention of anti-biotic resistance in livestock and aquatic production in the period 2017-2020, the Ministry of Agriculture and Rural Development, 2017.

[14]. TCVN 8342:2010, Fisheries and aquatic products - Detection of Salmonella by polymerase chain reaction $(\mathrm{PCR})$ technique. 
[15]. L. Q. Phong, S. Ueda, N. T. N. Hue, D. T. V. Khanh, H. T. A. Van, T. T. T. Nga, I. Hirai, T. Nakayama, R. Kawahara, D. T. Hung, V. Q. Mai, and Y. Yamamoto, "Characteristics of extended-spectrum $\beta$-Lactamase producing Escherichia coli in retail meats and shrimp at a local market in Vietnam," Foodborne Pathogens and Disease, vol. 12, no. 8, pp. 719-725, 2015.

[16]. D. J. Eaves, L. Randall, D. T. Gray, A. Buckley, M. J. Woodward, A. P. White, and L. J. V. Piddock, "Prevalence of mutations within the quinolone resistance determining region of $g y r \mathrm{~A}, g y r \mathrm{~B}$, parC, and parE and association with antibiotic resistance in quinolone resistant Salmonella enterica," Antimicrobial Agents and Chemotherapy, vol. 48, no. 10, pp. 4012-4015, 2004.

[17]. D. N. Thuy, C. H. Phu, V. T. Huong, D. T. Hao, N. X. Huyen, and N. B. Hue, "Assessment of infection of desease-causing bacteria in fresh pork in Hanoi," Journal of Science Engineering in Veterinary, vol. 3, no. 8, pp. 48-54, 2006.

[18]. T. T. T. Giang, N. T. Nguyet, N. V. Tri, N. T. Le, V. X. Van, U. N. D. Ninh, P. M. Thu, and C. H. Nghia, "Survey of bacterial infection and anti-biotic resistance ability of isolated $E$. coli from food at Pasteur Institute," Journal of Science, University of Pedagoy, Ho Chi Minh city, 2014.

[19]. T. H. Thai, T. Hiraia, N. T. Lan, R. Yamaguchi, "Antibiotic resistance profiles of Salmonella serovars isolated from retail pork and chicken meat in North Vietnam," International Journal of Food Microbiology, vol. 156, no. 2, pp. 147-151, 2012.

[20]. T. T. T. Nga, L. Q. Phong, N. T. N. Duyen, D. T. V. Khanh, V. Q. Mai, L. X. Huy, and D. T. Hung, "Current situation of anti-biotic resistance of strains of Salmonella spp. isolated from fresh meat products in the Central Provinces," Journal of Preventive Medicine, vol. 29, no. 11, 2019.

[21]. Ministry of Health, "Guidelines for the use of anti-biotics," Medicine Publisher, 2015.

\section{Đặc điểm kháng kháng sinnh nhóm Quinolone của Salmonella spp. sinh beta-lactamase phân lập từ thịt tươi sống trên địa bàn thành phố Hổ Chí Minh}

\section{Trương Huỳnh Anh Vũ ${ }^{1,2}$, Nguyễn Hoàng Khuê Tú̉, Huỳnh Yên Hà ${ }^{1}$ Chu Vân Hải $i^{1}$ Nguyễn Anh Đức ${ }^{3}$}

${ }^{1}$ Phòng Vi sinh, Trung tâm Dịch vụ Phân tích Thí nghiệm thành phố Hồ Chí Minh, Việt Nam ${ }^{2}$ Khoa Khoa học Sinh học, Truờng Đại học Nông Lâm thành phố Hồ Chí Minh, Việt Nam ${ }^{3}$ Bộ môn Công nghệ Sinh học, Trường Đại học Quốc tế, Đại học Quốc gia thành phố Hồ Chí Minh, Việt Nam

\section{Tóm tắt}

Trong nghiên cứu này, tổng số 380 mẫu thịt (heo, bò, gà) tươi sống đã được lấy ngẫu nhiên tại các chợ truyền thống thuộc trên địa bàn thành phố Hồ Chí Minh. Salmonella spp. được định tính bằng kỹ thuật nuôi cấy theo ISO 6579-1:2017 và khẳng định bằng kỹ thuật PCR (TCVN 8342:2010), đánh giá đặc điểm nhạy cảm kháng sinh với 06 loại kháng sinh thuộc các nhóm 
$\beta$-lactam, quinolone bằng phương pháp khuếch tán trong thạch (Kirby-Bauer) và xác định kiểu gen đề kháng bằng kỹ thuật multiplex PCR. Kết quả cho thấy tỷ lệ nhiễm Salmonella spp. là 42,37\% (161/380), từng mẫu riêng biệt có tỷ lệ nhiễm lần lượt 50,00\% (63/126) đối với thịt heo, 49,62\% (65/131) đối với thịt gà và 26,83\% (33/123) đối với thịt bò. Các chủng Salmonella phân lập được kháng tất cả 06 loại kháng sinh thử nghiệm, cao nhất là ampicillin ( $\mathrm{AM})$ với 22,98\%, kế đến là nalidixic acid (NA) với 10,56\%. Tỷ lệ kháng với các kháng sinh khác như amoxicillin/ acid clavulanic (AMC), ceftazidime (CAZ), ciprofloxacin (CIP), ofloxacin (OFX) ở mức thấp $(<10 \%)$. Nghiên cứu đã phát hiện 37/161 (22,98\%) chủng Salmonella mang gen mã hóa ESBL thuộc nhóm TEM và $5 / 161(3,11 \%)$ chủng mang gen thuộc nhóm CTX. Không phát hiện trường hợp nào mang các gen thuộc nhóm SHV. Tất cả các chủng Salmonella spp. mang gen mã hóa $\beta$-lactamase đều phát hiện mang 04 gen đề kháng nhóm quinolone (bao gồm các gen gyrA, gyr $\mathrm{B}$ kháng nalidixic acid; gen parC, parE kháng ofloxacin và ciprofloxacin). Các chủng có kiểu hình gen blaTEM-gyrA/B-parC/E chiếm tỷ lệ phát hiện cao hơn kiểu hình blaCTX-gyrA/B-parC/E và $b l a \mathrm{TEM} / \mathrm{CTX}-g y r \mathrm{~A} / \mathrm{B}-p a r \mathrm{C} / \mathrm{E}$ lần lượt là $100 \%, 40,54 \%$ và $5,41 \%$. Dũ liệu này chỉ ra rằng Salmonella có nguôn gốc từ sản phẩm thịt tươi sống có khả năng kháng kháng sinh thuộc 2 nhóm $\beta$-lactam và quinolone ở mức đáng báo động. Vì vậy, các chương trình giám sát, kiểm soát Salmonella và tình hình sử dụng kháng sinh ở Việt Nam cần được thiết lập để bảo vệ sức khoẻ người tiêu dùng. Kết quả của nghiên cứu này còn cung cấp thêm bằng chứng trực tiếp về tình trạng nhiễm Salmonella trong thực phẩm và sự lưu hành các chủng kháng kháng sinh ở thành phố Hồ Chí Minh.

Tù khóa: beta-lactam, kháng kháng sinh, quinolone, Salmonella, thịt bán lẻ. 